\title{
Pengaruh Tingkat Margin dan Pelayanan Terhadap Kepuasan Nasabah Pada Pembiayaan Murabahah di BPRS Metro
}

\author{
Enneng Nisa Alfiani Safitri \\ Daarut taubid (DT) peduli metro \\ enneng.nisa@gmail.com
}

Diterima: Oktober 2019

Direvisi : November 2019

Diterbitkan: November 2019

\begin{abstract}
Abstrak: The existence of Islamic Banking is inseparateable from margin and services. Customes begin to be selective in places their financing. Its making islamic banks to take a few policies in determining competitive margin and good services. So its expected that custumers can achieve the value of satisfaction in islamic banks. The main goals is custumers can choose to use the services of islamic banks that can develops islamic banking in Indonesia.
\end{abstract}

The research used quantitative appoach with the purpose to reseaching The Effect of Margin Level And Services To Satisfaction Of Murababah Financing Costumers In BPRS Metro Madani. Result of this research is the factors that most influence the financing product in BPRS Metro Madani is Services. On Beta testing can be seen that the value of Margin Level V ariable (X1) is 0,388 wheareas for value of Services V ariable (X2) is 0,754. That shows that Beta of $X 1<X 2$ its means Services is the main factors of satisfaction on Murabahab Financing Custumers In BPRS Metro Madani Metro City.

Keywords: Islamic Banking, Customer, Margin, Satisfaction, Services.

Abstrak : Keberadaan bank berprinsip syariah tidak terlepas dari faktor margin dan pelayanan. Nasabah mulai selektif dalam menentukan tempat untuk melakukan pembiayaan. Hal tersebut membuat bank syariah untuk mengambil kebijakan penetapan margin yang kompetitif dan pelayanan yang baik diharapkan nasabah bisa mencapai nilai kepuasan pada bank syariah. Tujuan utamanya agar nasabah bisa memilih untuk menggunakan jasa bank syariah yang berdampak pada berkembangnya perbankan syariah di Indonesia.

Penelitian ini menggunakan pendekatan kuantatif dengan tujuan untuk meneliti pengaruh tingkat margin dan pelayanan terhadap kepuasan nasabah di BPRS Metro Madani. Hasil dari penelitian ini yaitu faktor yang paling memberikan pangaruh pada produk pembiayaan Murabahah di BPRS Metro Madani Kota Metro adalah pelayanan. Pada Pengujian Beta dapat dilihat bahwa nilai pada Variabel Tingkat Margin (X1) adalah sebesar 0,388 sementara untuk Variabel Pelayanan (X2) adalah sebesar 0,754. Hal ini menunjukan bahwa Beta X1 < Beta X2 yang memiliki arti faktor pelayanan adalah faktor dominan pada kepuasan nasabah. Sehingga pelayanan menjadi faktor kepuasan nasabah pembiayaan murabahah pada BPRS Metro Madani Kota Metro.

Kata Kunci: Perbankan Syariah, Nasabah, Margin, Kepuasan, Pelayanan.

\section{A. Latar Belakang}

\section{Permasalahan Penelitian}

Bank Pembiayaan Rakyat Syariah (BPRS) adalah bank yang tidak memberikan jasa dalam lalu lintas pembayaran ${ }^{1}$, yang dalam pelaksanaan kegiatan usahanya berdasarkan prinsip syariah. Bank pembiayaan Rakyat Syariah menerima simpanan hanya dalam bentuk deposito berjangka, tabungan dan/atau bentuk lainnya yang dipersamakan dengan itu. Dengan semakin berkembangnya kebutuhan masyarakat, tugas BPRS tidak hanya ditujukan bagi masyarakat

\footnotetext{
${ }^{1}$ M. Nur Rianto Al Arif, Lembaga Keuangan Syariah, (Bandung : CV. Pustaka Setia, 2012),
} 
pedesaan atau pinggiran, tetapi juga mencakup pemberian jasa perbankan bagi masyarakat golongan ekonomi lemah di daerah perdesaan. Hal ini untuk menghindari agar mereka tidak terjebak oleh rentenir yang menerapkan bunga berbunga ${ }^{2}$.

Produk Pembiayaan Akad Murabahah pada Bank Syariah bertujuan untuk memberikan pembiayaan jangka pendek kepada klien untuk membeli barang walaupun klien tersebut tidak memiliki uang tunai yang cukup untuk membayar. Pembiayaan Akad Murabahah menurut Fatwa DSN MUI N0.04/DSN-MUI/IV/2000, adalah menjual sesuatu barang dengan menegaskan harga belinya kepada pembeli dan pembeli membayarnya dengan harga yang lebih sebagai laba. ${ }^{3}$

Pembiayaan Akad Murabahah merupakan jual beli secara angsuran dengan menggunakan prinsip syariah. Nasabah yang menggunakan produk jual beli ini bisa disebut dengan konsumen (pembeli) sedangkan Bank Syariah adalah Penjual. Eksistensi produk ini tentu tidak terlepas dari peran internal dan eksternal. Peran internal adalah pelaku perbankan (Pegawai Bank Syariah) yang menjalankan produk ini dengan tetap berpegang teguh dengan nilai syariat dan selalu berusaha berinovasi mengikuti arus jaman yang semakin maju. Implikasinya adalah peran eksternal (konsumen) memilih menggunakan produk ini sebagai media memenuhi kebutuhan akan suatu barang. Faktor kepuasan inilah yang menjadikan nasabah kembali mempercayakan pembiayaannya pada produk ini.

Brown yang juga mendefinisikan kepuasan konsumen adalah kondisi terpenuhinya kebutuhan, keinginan dan harapan konsumen terhadap sebuah produk dan jasa. Konsumen yang puas mengonsumsi produk tersebut secara terus menerus, mendorong konsumen untuk loyal terhadap suatu produk dan jasa tersebut dari mulut ke mulut. ${ }^{4}$

Harga pada Pembiayaan Akad Murabahah ditunjukkan dengan margin. Margin keuntungan adalah presentase tertentu yang ditetapkan pertahun perhitungan margin keuntungan secaraharian, maka jumlah hari dalam setahun ditetapkan 360 hari; perhitungan margin keuntungan secara bulanan, maka setahun ditetapkan 12 bulan $^{5}$. Margin adalah harga atau laba yang disepakati oleh penjual dan pembeli. Akad ini merupakan salah satu bentuk natural certainty contracts, karena dalam Pembiayaan Akad Murabahah ditentukan berupa required rate of profit-nya (keuntungan yang ingin diperoleh) ${ }^{6}$. Pelayanan dapat diartikan setiap tindakan membantu, menolong, memudahkan, menyenangkan dan manfaat bagi orang lain. Pelayanan nasabah adalah rangkaian kegiatan sikap dan perilaku petugas bank dalam menerima kehadiran atau berkomunikasi dengan nasabah secara langsung

2 Ibid., h. 199

3 Adiwarman Karim, Bank Islam: Analisis Fiqih Dan Keuangan, ( Jakata: Raja Grafindo Persada, 2013), h.494

${ }^{4}$ Vinna Sri Yuniarti, Perilaku Konsumen, (Bandung: CV Pustaka Setia, 2015), h.233

${ }^{5}$ Adiwarman Karim, Bank Islam.h. 279-280

${ }^{6}$ Ibid., h. 113 
maupun tidak langsung7. Maka besaran margin bisa menjadi faktor harga dan pelayanan merupakan faktor kualitas pelayanan yang dapat mempengaruhi kepuasan nasabah. Besaran margin dan pelayanan yang mendukung di pada lingkungan perbankan membuat masyarakat lebih selektif dalam memilih perbankan tempat mengajukan pembiayaan. Faktor ini perlu dikaji guna kedepannya nasabah yang kembali mengggunakan kembali produk pada bank ini meningkat.

Nasabah Pembiayaan Akad Murabahah pada tahun 2018 terhitung dari Januari-April sebanyak 205 nasabah $^{8}$ di BPRS Metro Madani Kota Metro. Tentunya hal ini tidak terlepas dari harga dan kualitas pelayanan yang diberikan oleh BPRS tersebut. Besaran margin 18\% pada Akad Pembiayaan Murabahah sebesar Rp. 30.000.000 lebih besar dari pada Bank Syariah yang berlokasi tidak jauh yaitu sebesar 2,04-2,28\% dengan plafond yang sama ${ }^{9}$. Sementara pada faktor pelayanan di BPRS tersebut, memberikan pelayanan yang lebih luwes dalam pelaksanaan akad, pelayanan jemput bola setiap hari untuk jasa transfer, tabungan dan angsuran. Faktor harga dan pelayanan itu pula yang membuat banyak nasabah pada BPRS Metro Madani mempercayakan dana mereka ${ }^{10}$.

BPRS merupakan lembaga keuangan syariah yang mampu memberikan pembiayaan yang bersaing dari segi harga dan kualitas pelayanan dari bank syariah lainnya yang sudah berdiri lebih dahulu. Mengingat BPRS adalah lembaga yang berfokus pada pembiayaan serta visi dari BPRS Metro Madani yang berimplimentasi pada membawa kemaslahatan ummat11. Harga dan kualitas pelayanan menjadi kunci dari eksistensi sebuah bank. Margin atau harga yang ditetapkan merupakan kebijakan yang diambil bank untuk mendapatkan laba namun tetap pada porsi jangkauan nasabah. Namun perbedaan yang signifikan pada besaran margin tentu akan berpengaruh pada kepuasan nasabah. Sudut pandang yang disadari oleh BPRS Metro Madani adalah perpektif mahal atau tidaknya sebuah harga, nasabah yang mampu menilainya. Hal yang perlu ditingkatkan untuk menutupi kekurangan adalah dengan meningkatkan faktor kepuasan lainnya.

\section{Identifikasi Masalah}

Latar belakang yang telah dipaparkan, maka dapat diidetifikasikan masalah yang terjadi di BPRS Metro Madani Kota Metro adalah:

a. Kepuasan nasabah BPRS Metro Madani tahun 2018 pada faktor margin dan pelayanan.

${ }^{7}$ M. Nur Rianto Al Arif, Dasar-Dasar Pemasaran Bank Syariah, (Bandung : Alfabeta, 2012), h. 212

${ }^{8}$ Hasil Prasurvey dengan salah satu Karyawan BPRS Metro Madani di bidang Makteing Financing, Bapak Diki pada Rabu, 04 April 2018.

${ }^{9}$ Brosur BRI Syariah Kota Metro.

${ }^{10}$ Hasil Wawancara dengan Ibu Surti Nasabah Pembiayaan Murabahah BPRS Metro Madani pada Kamis, 05 April 2018.

${ }^{11}$ Arsip Dokumen BPRS Metro Madani Kota Metro. 
b. Faktor Dominan yang mempengaruhi kepuasan nasabah BPRS Metro Madani Kota Metro 2018.

\section{Rumusan Masalah}

Berdasarkan latar belakang masalah yang telah diuraikan, maka dapat dirumuskan rumusan masalah penelitian yaitu:

a. Bagaimana pengaruh tingkat margin dan pelayanan terhadap kepuasan nasabah pada Pembiayaan Akad Murabahah di BPRS Metro Madani Kota Metro?

b. Apakah faktor tingkat margin atau pelayanan yang menjadi faktor dominan terhadap kepuasan nasabah pada Pembiayaan Akad Murabahah di BPRS Metro Madani Kota Metro?

\section{Metodologi Penelitian}

Variabel-variabel penelitian berdasarkan masalah, maka variabel pertama adalah "margin pembiayaan murabahah" yang diberi notasi (X1) dan "Pelayanan" yang diberi notasi (X2) merupakan variabel bebas atau independent variable. Sedangkan variabel kedua adalah "kepuasan nasabah" diberi notasi (Y) yang diposisikan sebagai variabel terikat atau dependen variable.

\section{a. Pendekatan Penelitian}

Penelitian ini menggunakan pendekatan penelitian kuantitatif. Pendekatan kuantitatif adalah merupakan metode penelitian yang dimaksudkan untuk menjelaskan fenomena dengan data-data numerik, kemudian dianalisis yang umumnya menggunakan statistik ${ }^{12}$.

\section{b. Jenis Penelitian}

Jenis Penelitian dalam penelitian ini adalah survei. Jenis penelitian survei ini adalah metode pengumpulan data dengan menggunakan instrumen untuk meminta tanggapan dari responden. Pada dasarnya survei terdiri dari wawancara dan kuesioner (Angket) ${ }^{13}$. Wawancara dilakukan dalam hubungan langsung atau bentuk tatap muka dan bentuk tidak langsung berupa kuisioner tertulis antara peneliti dengan nasabah yang melakukan pembiayaan murabahah pada BPRS Metro Madani Kota Metro.

\footnotetext{
${ }^{12}$ Uhar Suharsaputra, Metode Penelitian; Kuantitatif, Kualitatif dan Tindakan, (Bandung: PT Refika Aditama, 2012), h.50

${ }^{13}$ Suharsimi Arikunto, Prosedur Penelitian ; Suatu Pendekatan Praktik, (Jakarta: PT Rineka Cipta, 2010), h.268
} 


\section{Kajian Teoritik}

\section{a. Bank Pembiayaan Rakyat Syariah (BPRS)}

Pada UU Perbankan No.10 tahun 1998, disebutkan bahwa BPR adalah lembaga keuangan bank yang melaksanakan kegiatan usahanya secara konvensional atau berdasarkan prinsip syariah. Menurut Undang-Undang No 21 Tahun 2008 tentang perbankan syariah, bank pembiayaan rakyat syariah (BPRS) adalah bank syariah yang dalam kegiatannya tidak memberikan jasa dalam lalu lintas pembayaran. ${ }^{14}$

Pelaksanaan BPR yang melakukan kegiatan usaha berdasarkan prinsip syariah selanjutnya diatur menurut Surat Keputusa Direktur Bank Indonesia No. 32/36/KEP/DIR/1999 tanggal 12 Mei 1999 tentang Bank Perkreditan Rakyat Berdasarkan Prinsip Syariah. ${ }^{15}$

\section{b. Murabahah}

Murabahah adalah jual beli barang pada harga asal dengan tambahan keuntungan yang disepakatai. Dalam murabahah penjual harus memberi tahu harga produk yang ia beli dan menentukan tingkat keuntngan sebagai tambahannya. ${ }^{16}$

Murabahah adalah transaksi jual beli dimana bank menyebut jumlah keuntungan. Bank bertindak sebagai penjual, sementara nasabah sebagai pembeli. Harga jual adalah harga beli bank dari pemasok ditambah keuntungan (margin). Kedua belah pihak harus menyepakati harga jual dan jangka waktu pembayaran. Harga jual dicantumkan dalam akad jual beli dan telah disepakari tidak dapat berubah selama akad. ${ }^{17}$

Aplikasi dalam Perbankan Syariah, Pembiayaan Murabahah adalah suatu pembiayaan dengan akad jual beli barang pada harga asal dengan tambahan keuntungan yang disepakati, dimana penjual harus memberi tahu harga produk yang ia beli dan menentukan suatu tingkat keuntungan sebagai tambahannya. ${ }^{18}$

Bank syariah menerapkan marjin keuntungan terhadap produk-produk pembiayaan yang berbasis Natural Certainty Contract (NCC), yakni akad bisnis

${ }^{14}$ M. Nur Rianto Al Arif, Lembaga Keuangan., h.197-198

${ }^{15}$ Heri Sudarsono, Bank dan Lembaga Keuangan Syariah; Deskripsi dan Ilustrasi, (Yogyakarta: Ekonisia, 2013), h.93

${ }^{16}$ Muhammad Syafii Antonio, Bank Syariah; Dari Teori ke Praktek, (Jakarta: Gema Insani, 2016), h.101

${ }^{17}$ Adiwarman Karim, Bank Islam: Analisis Fiqih dan Keuangan cetakan ke 9, ( Jakata: Raja Grafindo Persada, 2013), h.98

${ }^{18}$ Muhammad Syafii Antonio, Bank Syariah, (Jakarta: Gema Insani, 2016), h.101 
yang memberikan kepastian pembayaran, baik dari segi jumlah (amount) maupun waktu (timing), seperti pembiayaan murabahah ${ }^{19}$.

Rukun jual beli Murabahah sama halnya dengan jual beli pada umumnya, yaitu adanya pihak penjual, pihak pembeli, barang yang dijual, harga dan akad atau ijab qobul 20 . Semantara syarat jual beli Murabahah adalah:

1) Akad harus jelas, baik ijab maupun qobul. Dalam akad harus ada kesesuaian antara ijab dan qobul, dan kesinambungan antara keduanya.

2) Syarat sah jual beli Murabahah yaitu:

a) Akad jual beli yang pertama harus sah.

b) Pembeli harus mengetahui harga awal barang yang menjadi objek jual beli.

c) Barang yang menjadi objek meripakan komoditas mitsli atai ada padanannya serta dapat diukur, ditakar, ditimbang atau jelas ukuran, kadar, dan jenisnya.

d) Jual beli pada akad yang pertama bukan barter barang dengan barang ribawi yang tidak boleh ditukar dengan barang sejenis.

e) Keuntungan atau laba harus diketahui masing-masing pihak yang bertransaksi, baik penjual maupun pembeli, apabila keuntungan tidak diketahui oleh pembelu, maka tidak dapat dikatakan sebagai jual beli murabahah. ${ }^{21}$

\section{c. Pelayanan}

Pada Bahasa Indonesia, Pelayanan juga disebut jasa atau servis, tergantung pada konteksnya ${ }^{22}$. Kotler mendefinisikan jasa sebagai setiap tindakan atau perbuatan yang dapat ditawarakan oleh suatu pihak kepada pihak lain yang pada dasarnya bersifat intangible (tidak berwujud fisik) dan tidak menghasilkan kepemilikan sesuatu.

Sementara Gronross mendefinisikan "jasa sebagai proses yang terdiri atas serangkaian aktivitas intangible yang biasanya (namun tidak harus selalu) terjadi pada interaksi atanra pelanggan dan karyawan jasa dan/atau sumber daya fisik atau barang dan/atau sistem penyedia jasa, yang disediakan sebagai solusi atas masalah pelanggan." 23

Ada empat karakteristik pelayanan yaitu:

1) Intangibility

2) Heterogeneity/Variability/Inconsistency

${ }^{19}$ Adiwarman Karim, Bank Islam., h.279

h.71

${ }^{20}$ Imam Mustofa, Fiqh Mu'amalah Kontemporer, (Jakarta: PT Raja Grafindo Persada, 2016),

${ }^{21}$ Ibid., h.72-73

${ }^{22}$ Fandy Tjiptono dan Gregorius Chandra, Service, Quality and Satisfaction, (Yogyakarta: CV Andi Offset, 2011), h.12

${ }^{23}$ Fandy Tjiptono dan Gregorius Chandra, Service, Quality., h.17 


\section{3) Inseparability \\ 4) Perishability 24}

\section{d. Kepuasan Nasabah}

Pengertian kepuasan konsumen menurut Mowen dan Minor yang dikutip oleh Vinna Sri Yuniarti dalam Buku Berjudul Perilaku Konsumen bahwasannya kepuasan konsumen sebagai keseluruhan sikap yang ditunjukkan konsumen atas barang dan jasa setelah mereka memperoleh dan menggunakannya. Hal ini merupakan penilaian eveluatif pasca-pemilihan yang disebabkan oleh seleksi pembelian khusus dan pengalaman menggunakan atau mengonsumsi baerang dan jasa tersebut. Selain Mowen dan Minor ada Brown yang juga mendefinisikan kepuasan konsumen adalah konsidi terpenuhinya kebutuhan, keinginan dan harapan konsumen terhadap sebuah produk dan jasa. Konsumen yang puas mengonsumsi produk tersebut secara terus menerus, mendorong konsumen untuk loyal terhaap suatu produk dan jasa tersebut dari mulut ke mulut ${ }^{25}$.

Terdapat Lima faktor utama yang perlu di perhatikan dalam kaitannya dengan kepuasan konsumen antara lain:
1) Kualitas produk
2) Kualitas pelayanan
3) Emosional
4) Harga
5) Biaya

Menurut Kotler yang dikutip oleh Vinna SY bahwasannya ciri-ciri konsumen yang merasa puas sebagai berikut:

1) Loyal terhadap produk, yaitu membeli ulang dari produsen yang sama.

2) Adanya komunikasi dari mulut-kemulut yang bersifat positif, yaitu rekomendasi kepada calon konsumen lain dan mengatakan hal-hal yang baik mengenai produk dan perusahaan produk yang dikonsumsi.

3) Perusahaan menjadi pertimbangan utama, yaitu ketika membeli merek lain, perusahaan yang telah memberikan kepuasan kepadanya akan menjadi pertimbangan utama. ${ }^{26}$

\section{B. Hasil dan Pembahasan}

\section{Uji Validitas dan Reliabilitas}

\section{a. Uji Validitas}

Uji coba ini dilakukan kepada 10 responden di luar responden sampel dan bertujuan untuk menguji kevalidan dari instrumen yang

\footnotetext{
${ }^{24}$ Ibid., h.35-41

${ }^{25}$ Vinna Sri Yuniarti, Perilaku Konsumen, (Bandung: CV Pustaka Setia, 2015), h.233

${ }^{26}$ Ibid., h.238-239
} 
digunakan dalam penelitian ini. Alat yang digunakan adalah Angket berisi pertanyaan (Kuisioner).

Kriteria pengujian validitas pada penelitian ini adalah pertanyaan yang berkorelasi positif memiliki instrumen yang valid.

Hasil uji validitas pada penelitian ini diperoleh hasil:

1) Koefisien korelasi dari butir 1 sampai 5 pada Faktor Margin (X1) berkorelasi positif, maka kesimpula yang bisa diambil adalah bahwa kuisioner margin ini memiliki instrumen valid.

2) Koefisien korelasi dari butir 1 sampai 5 pada Faktor Pelayanan (X2) berkorelasi positif, maka kesimpula yang bisa diambil adalah bahwa kuisioner margin ini memiliki instrumen valid.

3) Koefisien korelasi dari butir 1 sampai 4 pada Faktor Kepuasan Nasabah (Y) berkorelasi positif, maka kesimpula yang bisa diambil adalah bahwa kuisioner margin ini memiliki instrumen valid.

\begin{tabular}{|c|c|c|c|}
\hline Variabel & Margin (X1) & Pelayanan (X2) & $\begin{array}{c}\text { Kepuasan Nasabah } \\
(\mathrm{Y})\end{array}$ \\
\hline Keterangan & Valid & Valid & Valid \\
\hline
\end{tabular}

Tabel 2.1

\section{b. Uji Reliabilitas}

Uji coba ini dilakukan kepada 10 responden di luar responden sampel dan bertujuan untuk menguji kevalidan dari instrumen yang digunakan dalam penelitian ini. Alat yang digunakan adalah Angket berisi pertanyaan (Kuisioner). Metode yang digunakan adalah One Shot. Metode ini menggunakan teknik pengukuran yang dilakukan hanya pada satu waktu, kemudian dilakukan perbandingan dengan pertanyaan lain atau dengan pengukuran korelasi antarjawaban ${ }^{27}$.

Kriteria pengujian reliabilitas pada penelitian ini adalah pada program SPSS, metode ini menggunakan Cronbach Alpha dimana kuisioner dikatakan reliabel jika nilai Cronbach Alpha lebih besar dari $0.60^{28}$. Hasil Uji Reliabilitas pada penelitian ini:

\begin{tabular}{|c|c|c|c|}
\hline Variabel & Margin (X1) & Pelayanan (X2) & $\begin{array}{c}\text { Kepuasan Nasabah } \\
\text { (Y) }\end{array}$ \\
\hline $\begin{array}{c}\text { Cronbach } \\
\text { Alpha }\end{array}$ & 0.77 & 0.79 & 0.77 \\
\hline
\end{tabular}

${ }^{27}$ Purbayu DS dan Ashari, Analisis Statistik., h.251

28 Ibid. 


\begin{tabular}{|l|l|l|l|}
\hline Keterangan & Reliabel & Reliabel & Reliabel \\
\hline
\end{tabular}

Tabel 2.2

Hasil penelitian menunjukkan bahwa Cronbach Alpha pada variabel Margin (X1) adalah sebesar 0,77. Hal ini dikatakatan reliabel karena 0,77 lebih besar dari pada ketentuan yaitu sebesar 0,60. Kemudian Cronbach Alpha pada variabel Pelayanan (X2) adalah sebesar 0,79. Hal ini dikatakatan reliabel karena 0,79 lebih besar dari pada ketentuan yaitu sebesar 0,60. Cronbach Alpha pada variabel Kepuasan Nasabah (Y) adalah sebesar 0,77. Hal ini dikatakatan reliabel karena 0,77 lebih besar dari pada ketentuan yaitu sebesar 0,60 .

\section{Uji Normalitas}

Pengujian Normalitas adalah pengujian tentang kenormalan distribusi data. Penggunaan uji normalitas karna ada analisis statistik parametik, asusmsi yang harus dimiliki oleh data bahwa data tersebut terdistribusi secara normal. Maksud data terdistribusi dengan nornal adalah bahwa data akan mengikuti bentuk distribusi normal. Distribusi normal data dengan bentuk distribusi normal dimana data memusat pada nilai rata-rata dan median. ${ }^{29}$

\section{a. Grafik Histogram}

Normalitas dari suatu data dapat dilihat dengan menggunakan grafik histogram dengan kriteria bentuk data yang terdistribusi secara normal akan mengikuti pola distribusi normal dimana grafiknya mengikuti bentuk lonceng. ${ }^{30}$

Hasil dari penelitian grafik kepuasan nasabah mengikuti bentuk distribusi normal dengan bentuk histrogram yang hampir sama dengan bentuk distrbusi normal yaitu bentuk lonceng. Hal itu dapat dilihat pada gambar 1.1.

\section{Histogram}

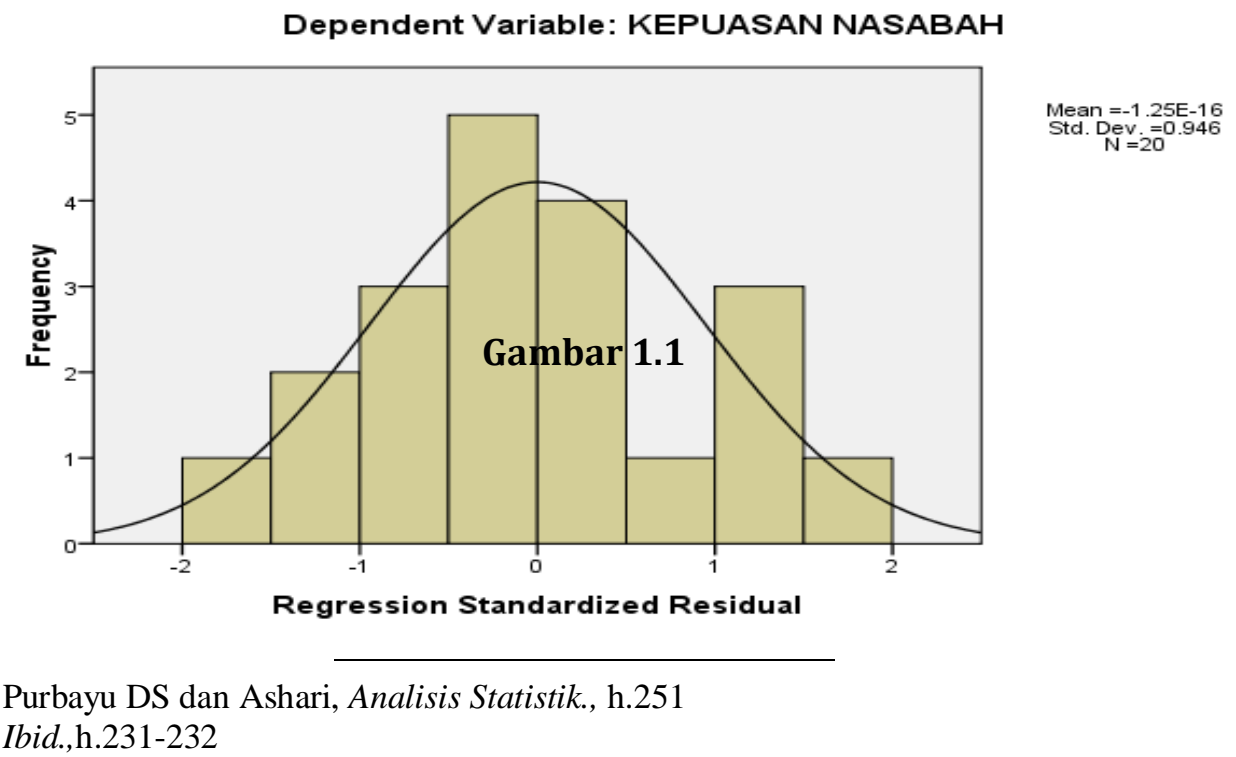

Finansia Volume2 Nomor 2 Juli-Desember 2019| 153 


\section{b. PP Plots}

Normalitas dari suatu data dapat dilihat dengan menggunakan grafik PP Plots dengan kriteria bentuk data yang terdistribusi secara normal akan bila nilai probalitias yang diharapkan adalah sama dengan nilai probabilititas pengamatan ditunjukan dengan garis diagonal yang merupakan perpotongan antara garis probabilitias harapan dan probabilitas pengamatan tidak menjauhi/menyipang jauh garis diagonal. ${ }^{31}$

Hasil dari penelitian grafik kepuasan nasabah mengikuti bentuk distribusi normal dengan bentuk PP Plots yang tidak menjauhi/menyipang jauh garis diagonal. Hal ini bisa dilihar pada gambar 1.2 berikut:

\section{Normal P-P Plot of Regression Standardized Residual}

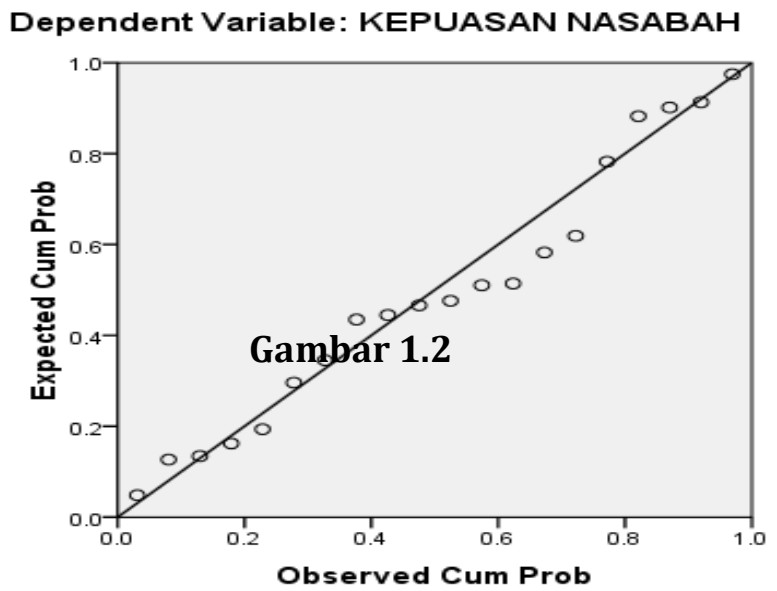

\section{Persamaan Regresi Linier Berganda}

\section{a. Analisis Korelasi Ganda (R)}

Analisis ini digunakan untuk mengetahui hubungan antara dua atau lebih variabel independen terhadap variabel dependen secara serentak. Koefisien ini menunjukkan seberapa besar hubungan yang terjadi antara variabel independen. Nilai $\mathrm{R}$ berkisar antara $0-1$, nilai semakin mendekati 1 bearti hubungan yang terjadi semakin kuat, sebaliknya mendekati 0 maka yang terjadi semakin lemah. Pedoman untuk memberikan interpretasi koefisien sebagai berikut ${ }^{32}$ :

$$
\begin{array}{ll}
0,00-0,199 & =\text { Sangat Rendah } \\
0,20-0,399 & =\text { Rendah } \\
0,40-0.599 & =\text { Sedang } \\
0,60-0,799 & =\text { Kuat } \\
0,80-1,000 & =\text { Sangat kuat }
\end{array}
$$

${ }^{31}$ Purbayu DS dan Ashari, Analisis Statistik dengan MS Excel dan SPSS. (Yogyakarta: CV Andi Offset. 2005), h.235

${ }^{32}$ Dwi Priyanto, Mandiri Belajar SPSS (Statistical Product and Service Solution) untuk Analisis Data dan Uji Statistik, (Yogyakarta: MediaKom, 2008) h.78 
Hasil dari Penelitian ini menunjukkan nilai yang diperoleh angka $\mathrm{R}$ sebesar 0,833 yang mana berada diantara 0,80 - 1,000. Dapat disimpulkan bahwa terjadi hubungan yang sangat kuat antara Tingkat Margin (X1) dan Pelayanan (X2) terhadap Kepuasan Nasabah.

\section{b. Analisis Determinasi $\left(\mathbf{R}^{2}\right)$}

Analisis determinasi dalam regresi linier berganda digunakan untuk mengetahui presentase sumbangan pengaruh variabel dependen terhadap variabel dependen. Koefisien ini menunjukkan seberapa besar presentase variabel independen yang digunakan dalam model mampu menjelaskan variasi variabel dependen. $\mathrm{R}^{2}$ sama dengan 0 maka tidak ada sedikitpun presentase sumbangan pengaruh variasi variabel dependen. Sebaliknya bila $\mathrm{R}^{2}$ sama dengan 1 maka presentase sumbangan pengaruh yang diberikan variabel independen terhadap variabel adalah sempurna atau variasi variabel independen yang digunakan dalam model 100\% menjelaskan variasi variabel dependen ${ }^{33}$.

Hasil dari penelitian diperoleh angka $\mathrm{R}^{2}$ sebesar 0,694 atau 69,4\%. Hal tersebut menunjukkan bahwa presentase sumbangan pengaruh variabel dependen Tingkat Margin (X1) dan Pelayanan (X2) adalah 69,4\% atau variasi variabel yang digunakan dalam model (Tingkat Margin dan Pelayanan) mampu menjelaskan 69,4\% variasi variabel Kepuasan Nasabah (Y). Sedangkan sisanya 30,6\% dipengaruhi oleh variabel lain yang tidak termasuk dalam model penelitian ini.

\section{c. Uji Koefisien Regresi Secara Bersama-sama (Uji F)}

Uji ini digunakan untuk mengetahi apakah variabel independen secara bersama-sama berpengaruh secara signifikan terhadap variabel dependen. Atau untuk mengetahui apakah model regresi dapat digunakan untuk memprediksi variabel dependen atau tidak. Signifikan bearti hubungan yang terjadi dapat berlaku di populasi (dapat digeneralisasikan). Kriteria Pengujian:

1) Ho diterima bila $F$ hitung $<F$ Tabel

2) Ho ditolak bila F hitung $>$ F Tabel. ${ }^{34}$

Hasil penelitian menunjukkan hasil $\mathrm{F}$ hitung sebesar 19,276. Sehingga $\mathrm{F}$ hitung $>\mathrm{F}$ tabel $(19,276>3,591)$ hal ini menunjukkan bahwa Ho ditolak. Dapat disimpulakan bahwa ada pengaruh signifikan antara Tingkat Margin dan Pelayanan secara bersama sama terhadap Kepuasan Nasabah.

33 Dwi Priyanto, Mandiri Belajar., h.79

34 Dwi Priyanto, Mandiri Belajar., h.82-83 


\section{d. Uji Koefisien Regresi Secara Parsial (Uji t)}

Uji ini digunakan untuk mengetahui apakah dalam model regresi variabel independen secara parsial (sebagian) berpengaruh signifikan terhadap variabel dependen ${ }^{35}$. Kriteria Pengujian:

1) Ho diterima jika $-t$ tabel $<t$ hitung $<t$ tabel

2) Ho ditolak jika -t hitung $<-t$ tabel atau t hitung $>t$ tabel

Hasil dari penelitian menunjukkan:

1) Nilai t hitung pada variabel (X1) Tingkat Margin adalah 2,518, yang mana hal ini menunjukkan bahwa Ho ditolak karena $t$ hitung $>t$ tabel $(2,518>2,109)$, artinya secara parsial ada pengaruh signifikan antara Tingkat Margin dan Kepuasan Nasabah.

2) Nilai thitung pada variabel (X2) Pelayanan adalah 5,622, yang mana hal ini menunjukkan bahwa Ho ditolak karena $t$ hitung $>t$ tabel $(5,622>$ $2,109)$, artinya secara parsial ada pengaruh signifikan antara Pelayanan dan Kepuasan Nasabah.

\section{e. Uji Koefisien Regresi Yang Distandarisasi (Beta)}

Koefisien regresi yang distandarisasi (Beta) ini digunakan untuk menganalisis kebenaran dari hipotesis kedua dalam penelitian ini, yaitu: faktor tingkat margin dan pelayanan terhadap kepuasan nasabah pada BPRS Metro Madani Kota Metro. Berdasarkan hasil analisis koefisien regresi yang distandarisasi diperoleh:

Beta X1 $=0,388$

Beta X2 $=0,754$

Hasil penelitian diatas dapat menyimpulakan faktor yang paling besar memberikan pangaruh pada produk pembiayaan murabahah di BPRS Metro Madani Kota Metro. Pada Pengujian Beta dapat dilihat bahwa nilai pada Variabel Tingkat Margin (X1) adalah sebesar 0,388 sementara untuk Variabel Pelayanan (X2) adalah sebesar 0,754. Hal ini menunjukan bahwa Beta X1 < Beta X2 yang memiliki arti faktor pelayanan adalah faktor dominan pada kepuasan nasabah di BPRS Metro Madani Kota Metro.

Hipotesis yang menyebutkan bahwa Pelayanan merupakan faktor dominan pada kepuasan nasabah di BPRS Metro Madani, diterima karena variabel yang memiliki nilai beta terbesar adalah Pelayanan dengan nilai beta sebesar 0,754 . 


\section{KESIMPULAN}

1. Presentase sumbangan pengaruh variabel dependen (Uji $R^{2}$ ) Tingkat Margin (X1) dan Pelayanan (X2) adalah 69,4\% atau variasi variabel yang digunakan dalam model (Tingkat Margin dan Pelayanan) mampu menjelaskan 69,4\% variasi variabel Kepuasan Nasabah (Y). Sedangkan sisanya 30,6\% dipengaruhi oleh variabel lain yang tidak termasuk dalam model penelitian ini. Selain itu pada Uji R terjadi hubungan yang sangat kuat antara Tingkat Margin (X1) dan Pelayanan (X2) terhadap Kepuasan Nasabah (Y). Serta terdapat pengaruh yang signifikan secara simultan (Uji F) pada Tingkat Margin (X1) dan Pelayanan (X2) terhadap Kepuasan Nasabah pada Bank Pembiayaan Rakyat Syariah (BPRS) Metro Madani Kota Metro. Hal ini juga terjadi pada pengujian secara parsial (Uji T). Tingkat Margin (X1) dan Pelayanan (X2) memiliki pengaruh yang signifikan terhadap Kepuasan Nasabah (Y).

2. Faktor yang paling besar memberikan pangaruh pada produk pembiayaan murabahah di BPRS Metro Madani Kota Metro. Pada Pengujian Beta dapat dilihat bahwa nilai pada Variabel Tingkat Margin (X1) adalah sebesar 0,388 sementara untuk Variabel Pelayanan (X2) adalah sebesar 0,754. Hal ini menunjukan bahwa Beta X1 < Beta X2 yang memiliki arti faktor pelayanan adalah faktor dominan pada kepuasan nasabah di BPRS Metro Madani Kota Metro 


\section{Daftar Pustaka}

Adiwarman Karim, Bank Islam: Analisis Fiqih Dan Keuangan, (Jakarta: Raja Grafindo Persada, 2013).

Dwi Priyanto, Mandiri Belajar SPSS (Statistical Product and Service Solution) untuk Analisis Data dan Uji Statistik, (Yogyakarta: Media Kom, 2008).

Fandy Tjiptono dan Gregorius Chandra, Service, Quality and Satisfaction, (Yogyakarta: CV Andi Offset, 2011).

Heri Sudarsono, Bank dan Lembaga Keuangan Syariah; Deskripsi dan Ilustrasi, (Yogyakarta: Ekonisia , 2013).

Imam Mustofa, Fiqh Mu'amalah Kontemporer, (Jakarta: PT Raja Grafindo Persada, 2016).

M. Nur Rianto Al Arif, Dasar-Dasar Pemasaran Bank Syariah, (Bandung: Alfabeta, 2012).

------, Lembaga Keuangan Syariah, (Bandung: CV. Pustaka Setia, 2012).

Muhammad Syafii Antonio, Bank Syariah; Dari Teori ke Praktek, (Jakarta: Gema Insani, 2016).

Purbayu BS danAshari, Analisis Statistika dengan MS Excel dan SPSS, (Yogyakarta: CV Andi Offset, 2005)..

Suharsimi Arikunto, Prosedur Penelitian ; Suatu Pendekatan Praktik, (Jakarta: PT Rineka Cipta, 2010).

Uhar Suharsaputra, Metode Penelitian; Kuantitatif, Kualitatif dan Tindakan, (Bandung: PT Refika Aditama, 2012).

Vinna Sri Yuniarti, Perilaku Konsumen, (Bandung: CV Pustaka Setia, 2015). 